\title{
Role of Macrophages in the Development of Pancreatic Islet Injury in Spontaneously Diabetic Torii Rats
}

\author{
Chie INOKUCHI $^{1,2)}$, Haruyasu UEDA ${ }^{2,3)}$, Tomoya HAMAGUCHI ${ }^{1)}$, Jun-ichiro MIYAGAWA ${ }^{1)}$, \\ Masami SHINOHARA ${ }^{4)}$, Haruki OKAMURA ${ }^{2)}$, and Mitsuyoshi NAMBA ${ }^{1)}$ \\ ${ }^{1)}$ Division of Diabetes and Metabolism, Department of Internal Medicine, and ${ }^{2)}$ Institute for Advanced \\ Medical Sciences and the Department of Emergency and Disaster Medicine, Hyogo College of \\ Medicine, 1-1 Mukogawa-cho, Nishinomiya, Hyogo 663-8501, ${ }^{3)}$ Department of Pharmacy \\ School of Pharmacy, Hyogo University of Health Sciences, 1-3-6 Minatojima, Chuo-ku, \\ Kobe 650-8530, and ${ }^{4}$ Planning and Development Section, CLEA Japan Inc., \\ 1-2-7 Higashiyama, Meguro-ku, Tokyo 153-8533, Japan
}

\begin{abstract}
Spontaneously diabetic Torii (SDT) rats were established from Sprague-Dawley (SD) rat and are used as an animal model of type 2 diabetes mellitus. In the present study, the mechanism of the development of injury in the pancreas of these rats was examined focusing on the role of monocytes/macrophages. The number of lymphocytes and monocytes in the circulation of SDT rats increased with age, reaching a plateau at around 9 weeks of age and remaining at that level thereafter. The number of leukocytes in SDT rats was almost twice that of wild-type SD rats. Serum IL-18 levels began to increase at 8 weeks of age, forming a prominent peak at 9 weeks of age. In parallel with this, serum levels of $\mathrm{NO}_{2} / \mathrm{NO}_{3}$ showed an abrupt rise and decline. Spleen cells prepared from 9-week-old SDT rats expressed high levels of IFN- $\gamma$ in response to IL-18, while those from 9-week-old wild-type SD rats did not. Immunohistochemical analysis revealed marked infiltration of $\mathrm{CD} 68^{+}$cells in the islets of SDT rats. Treatment of SDT rats with $\mathrm{Cl}_{2} \mathrm{MDP}$-liposomes reduced the number of monocytes as well as levels of $\mathrm{NO}_{2} / \mathrm{NO}_{3}$ in the circulation. Consistent with this, the number of infiltrated $\mathrm{CD}^{+} 8^{+}$cells in the islets was reduced in SDT rats treated with $\mathrm{Cl}_{2} \mathrm{MDP}$-liposomes. These results suggest that macrophages are involved in pancreatic islet injury in SDT rats through excess production of NO induced by IL-18 which increases transitorily at around 9 weeks of age.
\end{abstract}

Key words: $\mathrm{Cl}_{2} \mathrm{MDP}$-liposomes, IL-18, monocytes/macrophage, NO, SDT rat

\section{Introduction}

Male SDT rats, known as a model of non-obese type 2 diabetes, develop hyperglycemia without obesity at around 20 weeks of age and manifest nephropathy and ocular complications such as cataract and proliferative retinopathy [30]. At 8-10 weeks of age, SDT rats manifest microvascular abnormalities such as congestion and hemorrhage in pancreatic islets [20]. At around 9 weeks of age, invasion of inflammatory cells into the pancreas and destruction of $\beta$-cells are observed [20]. Fibrosis in the pancreas occurs starting at about 20 weeks of age

(Received 5 January 2009 / Accepted 31 March 2009)

Address corresponding: M. Namba, Division of Diabetes and Metabolism, Department of Internal Medicine, Hyogo College of Medicine, 1-1 Mukogawa-cho, Nishinomiya, Hyogo 663-8501, Japan 
[20]. The invasion of inflammatory cells into the pancreas continues throughout the life of SDT rats, and high levels of glucose are also maintained in the blood [30]. Interestingly, however, SDT rats live long, for more than 2 years, without fatal complications even in the absence of exogenous administration of insulin.

Although diabetes of SDT rats has been considered as type 2, the pancreas of SDT rats also manifests features of type 1 diabetes, such as vigorous cell invasion [20]. Type 1 diabetes mellitus is an autoimmune disease that results in destruction of insulin-producing $\beta$-cells in the pancreatic islets. A variety of inflammatory cells and mediating molecules including cytokines and oxygen radicals are involved in the destruction of islet $\beta$-cells [19]. In non-obese diabetic (NOD) mice, used widely as a model of type 1 diabetes, macrophages play a role in the initiation and progression of autoimmune diabetes. Macrophages accumulate around the islets at 4-5 weeks of age prior to the peri-insular concentration of lymphocytes and later infiltrate into the islets $[14,28]$. It has been shown that excess nitric oxide (NO) production by macrophages present continuously in the pancreas of NOD mice mediates $\beta$-cell damage $[2,3,5,16]$. It has also been shown that excess production of NO by macrophages is induced by IFN- $\gamma$, produced by lymphocytes in response to stimulation by IL-18 and IL-12 [4]. Histological studies show that the islets of SDT rats are invaded by various inflammatory cells, but whether these cells mediate $\beta$-cell injury, as in NOD mice, has not been investigated.

Macrophages play a role in the pathogenesis of various diseases as well as in host defense. Macrophage depletion can be achieved by systemic injection of liposomes containing clodronate [37]. Clodronate belongs to the family of bisphosphonates (BPs), bone-seeking agents that are potent inhibitors of osteoclasts. Like other BPs, clodronate has poor cell membrane permeability [27]. Liposomes are readily taken up by cells in the reticuloendothelial system, in particular by macrophages. Liposome-mediated delivery of clodronate inactivates and kills macrophages after effective phagocytosis [29] but is not toxic to nonphagocytic cells [37]. The action of liposomes is different from that of various immunosuppressant drugs which reduce leukocytes by production in bone marrow. In animal models, depletion of monocytes/macrophages using $\mathrm{Cl}_{2} \mathrm{MDP}$-liposomes has been shown to ameliorate immune thrombocytopenic purpura [1], vascular repair after mechanical arterial injury [7], pneumocystis pneumonia [17], and autoimmune hemolytic anemia [15].

In this study, we examined the possibility that macrophages may play a pivotal role in $\beta$-cell destruction in SDT rats and that systemic inactivation of macrophages might lead to attenuation of islet injury. The results show that depletion of macrophages by clodronate in liposome reduced pancreatic invasion of macrophages and destruction of islet $\beta$-cells.

\section{Materials and Methods}

\section{Animals}

Male SDT rats were provided by the animal control center of the SDT rat study group (Torii Pharmaceutical Company, Tokyo, Japan). Age-matched male SD rats were purchased from CLEA Japan Inc. (Tokyo, Japan). All experimental procedures were approved by the Animal Care Committee of Hyogo College of Medicine.

\section{Blood cell count}

Blood samples were collected from the cervical vein using heparinized syringes in tubes containing EDTA once a week. Red blood cells, leukocytes, and platelets were stained with hematoxylin-eosin (HE) and counted under a microscope.

\section{Flow cytometory}

Peripheral leukocytes were separated by density gradient centrifugation with Histopaque1083 ${ }^{\mathrm{TM}}$ (Sigma Aldrich, St. Louis, MO, USA) and incubated with FITCconjugated anti-rat CD8 and Gr-1 antibodies, phycoerythrin (PE)-conjugated anti-rat CD3 antibody, and cychrome-conjugated anti-rat CD4 and CD161a antibodies (BD Bioscience Pharmingen, San Jose, CA, USA) for $15 \mathrm{~min}$ at $4^{\circ} \mathrm{C}$. Cells were washed 3 times with staining buffer (PBS containing 2\% FCS and $0.05 \%$ $\mathrm{NaN}_{3}$ ) and analyzed by flow cytometory (Becton Dickinson).

\section{Assay of cytokines and NO metabolites}

Serum levels of cytokines were measured by ELISA. 
For the IL-18 assay, 96-well EIA plates were treated with $1 \mu \mathrm{g} / \mathrm{ml}$ of mouse anti-rat IL-18 antibody (R\&D Systems, MN, USA) diluted with PBS for $16 \mathrm{~h}$ at $4{ }^{\circ} \mathrm{C}$, washed with PBS containing $0.5 \%$ Tween 20 and incubated with blocking solution (PBS containing 1\% BSA) for $1 \mathrm{~h}$ at $37^{\circ} \mathrm{C}$. Samples were loaded in the wells, kept at $37^{\circ} \mathrm{C}$ for $3 \mathrm{~h}$, and incubated with $0.2 \mu \mathrm{g} / \mathrm{ml}$ of biotinylated anti-rat IL-18 antibody (R\&D Systems) overnight at $4^{\circ} \mathrm{C}$, and with $2.5 \mu \mathrm{g} / \mathrm{ml}$ of streptavidin-horseradish peroxidase (HRPO) for $30 \mathrm{~min}$ at $37^{\circ} \mathrm{C}$. Then, 3,3', 5,5' -tetramethylbenzidine (TMB) (Sigma Chemical, St. Louis, MO, USA) solution was added (50 $\mu \mathrm{l} /$ well) and incubated for $30 \mathrm{~min}$ at room temperature in the dark to develop color. The reaction was stopped by adding stop solution $\left(1 \mathrm{~N} \mathrm{H}_{2} \mathrm{SO}_{4}\right)$, and $\mathrm{OD}$ values at $450 \mathrm{~nm}$ were measured by a microplate reader system (Bio-Rad, CA, USA). IL-18 concentrations were calculated using the MPM-III computer program (Bio-Rad). Serum IL-12 p40 and IL-12p70 were measured by an ELISA kit purchased from BioSource (CA, USA). Serum levels of IFN- $\gamma$, IL-4, IL-6, IL-10, and TNF- $\alpha$ were measured by Bio-Plex ${ }^{\mathrm{TM}}$ Suspension Array System (Bio-Rad, CA, USA). IFN- $\gamma$ in the culture of splenocytes was assayed by an ELISA kit purchased from BioSource. NO metabolites were determined by a kit consisting of Griess reagents (Dojin Chemical Laboratory Institute, Kumamoto, Japan). $\mathrm{NO}_{2}$ in the culture supernatant of leukocytes was assayed by the Griess method.

\section{Cell cultures}

Splenocytes isolated from 4- to 10-week old SD and SDT rats were cultured in RPMI1640 medium (Sigma Aldrich) supplemented with $10 \%$ FCS, $10 \mathrm{mM}$ glutamine, $20 \mu \mathrm{M}$ 2-mercaptoethanol, penicillin (100 U/ml), and streptomycin $(100 \mu \mathrm{g} / \mathrm{ml})$. Leukocytes prepared from peripheral blood were cultured in the same medium lacking phenol red (Sigma Aldrich). Cells were plated on 48- or 96-well culture dishes at a cell density of $1 \times$ $10^{6}$ cells $/ \mathrm{ml}$, and cultured with $100 \mathrm{ng} / \mathrm{ml}$ recombinant rat IL-18 (Glaxo Smith Kline Pharmaceuticals, PA, USA) and IL-12 (R\&D Systems). The supernatants were collected and stored at $-80^{\circ} \mathrm{C}$ until use.

\section{Histological examination}

The pancreases from 4- and 9-week-old SDT rats were fixed in $4 \%$ paraformaldehyde at $4{ }^{\circ} \mathrm{C}$ overnight, embedded in paraffin, and cut into $3-\mu \mathrm{m}$ sections. The sections were stained with HE for observation under a light microscope. For immunohistochemical analysis of CD68, a marker of macrophage, sections were treated with $0.1 \%$ trypsin for $5 \mathrm{~min}$ at room temperature after de-paraffinization. The sections were stained by the avidin-biotin complex (ABC) method using Vectastain ABC Kit (Vector laboratories, CA, USA). The primary antibody used was mouse anti-rat CD68 (1:200 in PBS containing 1\% BSA) (Serotec Ltd., Oxford, UK). They were then incubated with biotinylated second antibodies for $30 \mathrm{~min}$, and then with $\mathrm{ABC}$ reagent for $30 \mathrm{~min}$. Positive reactions were visualized by developing color with peroxidase substrate solution containing 3,3'-diaminobenzidine tetrahydrochloride (DAB) (Zymed Laboratories, San Francisco, CA).

\section{Treatment with $\mathrm{Cl}_{2} \mathrm{MDP}$-liposomes}

Liposome encapsulated with clodronate $(25 \mathrm{mg} / \mathrm{kg})$ or PBS-liposomes were purchased from Katayama Chemical Industries Co., Ltd. (Osaka, Japan). Six-weekold SDT rats were intravenously injected with $\mathrm{Cl}_{2} \mathrm{MDP}$ liposomes ( $1 \mathrm{ml} / \mathrm{rat}$ ) or PBS-liposomes as a control once a week for 3 weeks. Seven days after the final injection, all the rats were euthanized for flow cytometory analysis of blood cells and histological analysis of the pancreas. Pancreatic islets infiltrated with inflammatory cells were counted and expressed as a proportion of the total islets of the same pancreas. More than 50 pancreatic islets were examined for each rat.

\section{Statistical analysis}

Data are expressed as mean $\pm \mathrm{SE}$. The statistical significance of the difference between two means was evaluated using Student's $t$-test. In these tests, $P$ values of $<0.05$ were considered to be significant.

\section{Results}

Age-dependent changes of leukocyte numbers in SD and SDT rats

The numbers of leukocytes in SDT and SD rats increased with age. The number of leukocytes in SDT rats was $6,888 \pm 599 / \mu 1$ at 4 weeks of age and 21,057 


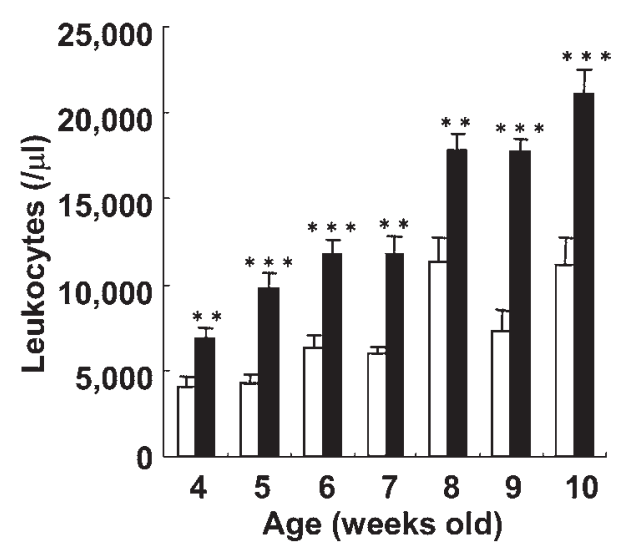

Fig. 1. Leukocytes in the blood in SD (open bars) and SDT (solid bars) rats at 4 to 10 weeks of age were counted. Data are expressed as the mean $\pm \mathrm{SE}$ of 8 rats of each group. $* P<0.05, * * P<0.01, * * * P<0.001$, comparison between SD and SDT rats (Student's $t$-test). $\pm 1,436 / \mu 1$ at 10 weeks of age. In SD rats, the leukocyte number was $4,063 \pm 541 / \mu 1$ at 4 weeks of age and 11,150 $\pm 1,574 / \mu 1$ at 10 weeks of age. The number of leukocytes in SDT rats was twice as large as that in SD rats throughout the experimental period (Fig. 1). SDT rats exhibited significant leukocytosis throughout the experimental period as compared to SD rats.

Analysis of the cellular composition of blood lymphocytes by FACS

The number of $\mathrm{CD}^{+} \mathrm{CD}^{+}$cells (helper/inducer $\mathrm{T}$ cells) in the circulation in SDT rats was $1,214 \pm 227 / \mu 1$ at 4 weeks of age and rose to $4,491 \pm 332 / \mu 1$ at 10 weeks of age. In SD rats, it was $994 \pm 149 / \mu 1$ at 4 weeks of age and 2,614 $\pm 352 / \mu 1$ at 10 weeks of age (Fig. 2A). Thus, the number of $\mathrm{CD}^{+} \mathrm{CD} 4^{+}$cells in SDT rats was about twice as large as that in SD rats. Similarly, the

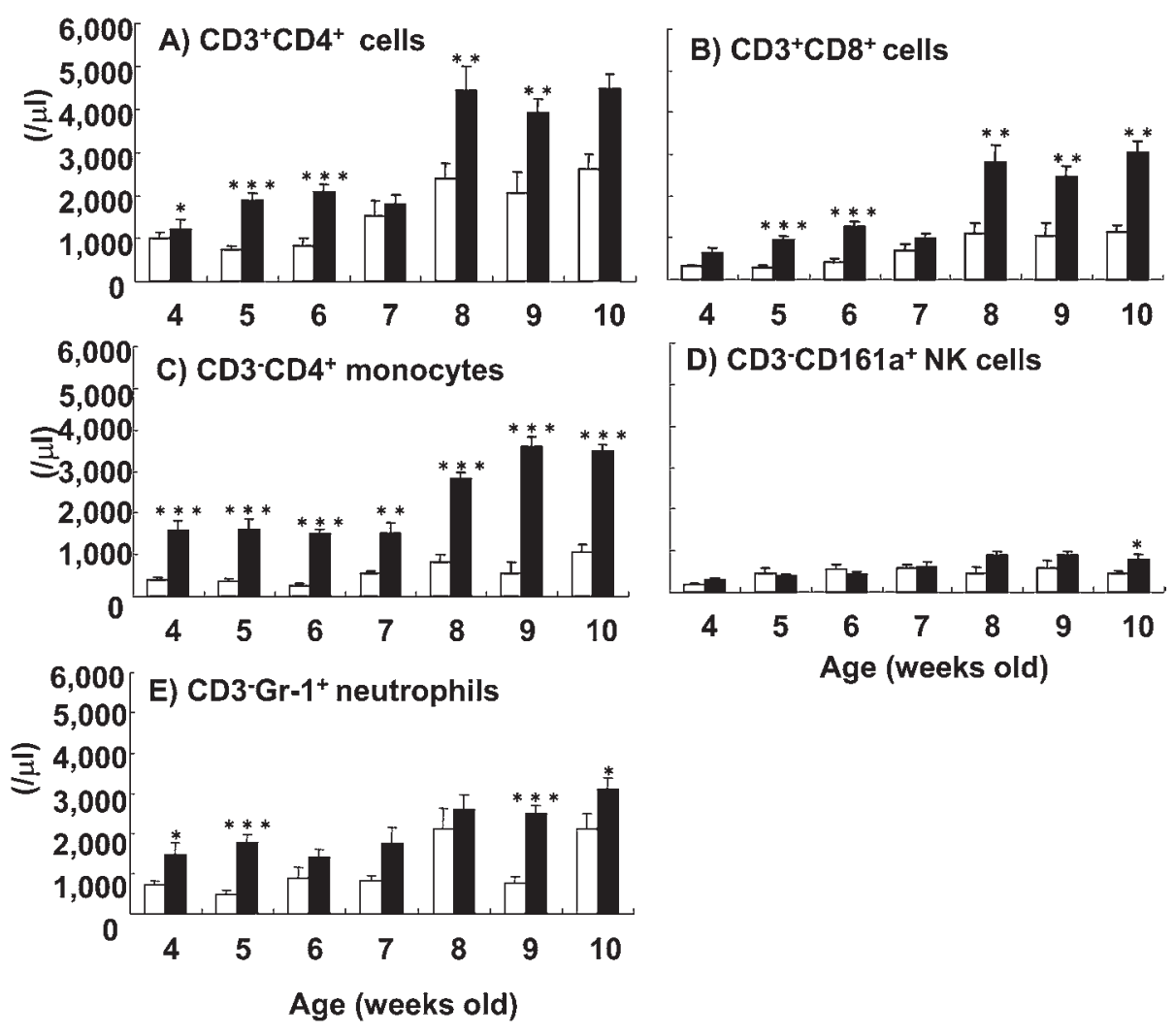

Fig. 2. Serum levels of $\mathrm{CD}^{+} \mathrm{CD} 4^{+}$cells $(\mathrm{A}), \mathrm{CD} 3^{+} \mathrm{CD} 8^{+}$cells (B), $\mathrm{CD} 3^{-} \mathrm{CD} 4^{+}$monocytes $(\mathrm{C})$, $\mathrm{CD}^{-} \mathrm{CD} 161 \mathrm{a}^{+} \mathrm{NK}$ cells (D), and $\mathrm{CD}^{-} \mathrm{Gr}-1^{+}$neutrophils (E) in SD (open bars) and SDT (solid bars) rats at 4 to 10 weeks of age were analyzed by flow cytometory. Data are expressed as the mean $\pm \mathrm{SE}$ of 8 rats of each group. $* P<0.05$, *** $P<0.01$, *** $P<0.001$, comparison between SD and SDT rats (Student's $t$-test). 

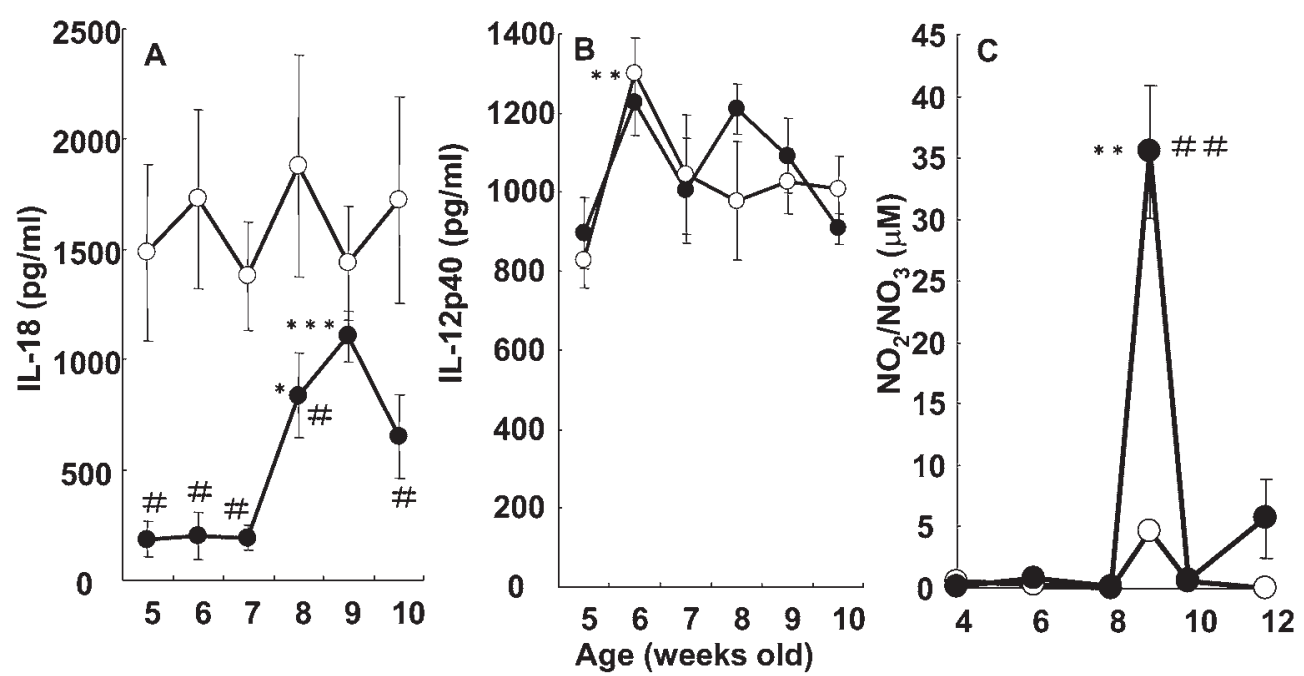

Fig. 3. Serum levels of IL-18 (A), IL-12p40 (B), and $\mathrm{NO}_{2} / \mathrm{NO}_{3}(\mathrm{C})$ were analyzed in SD and SDT rats of different ages. Open and closed circles indicate SD and SDT rats, respectively. Data are expressed as the mean \pm SE of 8 rats. $* P<0.05, * * P<0.01$, $* * * P<0.001$, comparison with 4 - or 5 -week-old rats and ${ }^{\#} P<0.05,{ }^{\# \#} P<0.01$, comparison between SD and SDT rats (Student's $t$-test).

number of $\mathrm{CD}^{+} \mathrm{CD}^{+}$cells (suppressor/killer $\mathrm{T}$ cells) was larger in SDT rats than in SD rats (Fig. 2B). The number of $\mathrm{CD}^{-} \mathrm{CD}^{+}$monocytes in SDT rats was more than three times as large as that in SD rats (Fig. 2C). The number of $\mathrm{CD}^{-} \mathrm{CD} 161 \mathrm{a}^{+} \mathrm{NK}$ cells was small throughout the experimental period (Fig. 2D). The number of $\mathrm{CD}^{-} \mathrm{Gr}-1^{+}$neutrophils in SDT rats was significantly larger than that in SD rats (Fig. 2E). Thus, $\mathrm{CD}^{+}{ }^{+} \mathrm{CD} 4^{+}$cells, $\mathrm{CD}_{3}{ }^{+} \mathrm{CD} 8^{+}$cells, $\mathrm{CD}^{-}{ }^{-} \mathrm{CD} 4^{+}$monocytes, and $\mathrm{CD}^{-} \mathrm{Gr}-1^{+}$neutrophils were significantly larger in number in SDT rats than in SD rats at 4 to 10 weeks of age.

Serum levels of $I L-18, I L-12 p 40, I L-12 p 70, I F N-\gamma, I L-4$, $I L-6, I L-10, T N F-\alpha$, and NO metabolites in SD and SDT rats

Expression of IL-12p40, IL-18, IFN- $\gamma$, and iNOS is known to be augmented in NOD mice [12, 25, 26, 31]. We analyzed whether SDT rats also produce these molecules at high levels. Serum levels of IL-18 in SD rats ranged from 1,300 to $1,900 \mathrm{pg} / \mathrm{ml}$ throughout the experimental period (Fig. 3A); those in SDT rats ranged from 180 to $200 \mathrm{pg} / \mathrm{ml}$ at 5 to 7 weeks of age, increasing to $1,234 \pm 314 \mathrm{pg} / \mathrm{ml}$ at 9 weeks, and then decreasing to $651 \pm 190 \mathrm{pg} / \mathrm{ml}$ at 10 weeks. Thus, serum IL-18 formed a prominent peak at 9 weeks of age in SDT rats (Fig.
3A). Serum levels of IL-12p40 ranged from 800 to 1,300 $\mathrm{pg} / \mathrm{ml}$ throughout the experimental period both in SD and SDT rats, and there was no significant difference between them (Fig. 3B). Serum levels of IL-12p70 were not detected throughout the experimental period both in SD and SDT rats (data not shown). There were also no significant differences in the levels of IFN- $\gamma$, IL-4, IL-6, IL-10, and TNF- $\alpha$ (data not shown).

Serum $\mathrm{NO}_{2} / \mathrm{NO}_{3}$ levels in SD rats were below $5.0 \mu \mathrm{M}$ throughout the experimental period, while in SDT rats, they were less than $5.0 \mu \mathrm{M}$ at 4 to 8 weeks of age, transiently increasing to $35.5 \pm 5.4 \mu \mathrm{M}$ at 9 weeks, and then decreasing to below $5.0 \mu \mathrm{M}$ at 10 weeks (Fig. 3C).

IFN- $\gamma$ production induced by IL-12 and IL-18 in splenocytes of $S D$ and $S D T$ rats

IFN- $\gamma$ produced in the culture of splenocytes from 4- to 10-week-old SD and SDT rats in the presence of IL-12 was less than $50 \mathrm{pg} / \mathrm{ml}$. In the presence of IL-18, levels of IFN- $\gamma$ produced in the culture of splenocytes from 4- to 8-week-old SDT rats were 4,000 to $6,700 \mathrm{pg} /$ $\mathrm{ml}, 11,623 \pm 3,244 \mathrm{pg} / \mathrm{ml}$ in 9-week-old SDT rats, and were $2,001 \pm 400 \mathrm{pg} / \mathrm{ml}$ in 10 -week-old SDT rats. In the presence of IL-18, splenocytes from SDT rats of 9 weeks of age produced higher levels of IFN- $\gamma$ than those from age-matched SD rats (Fig. 4A). Although a com- 


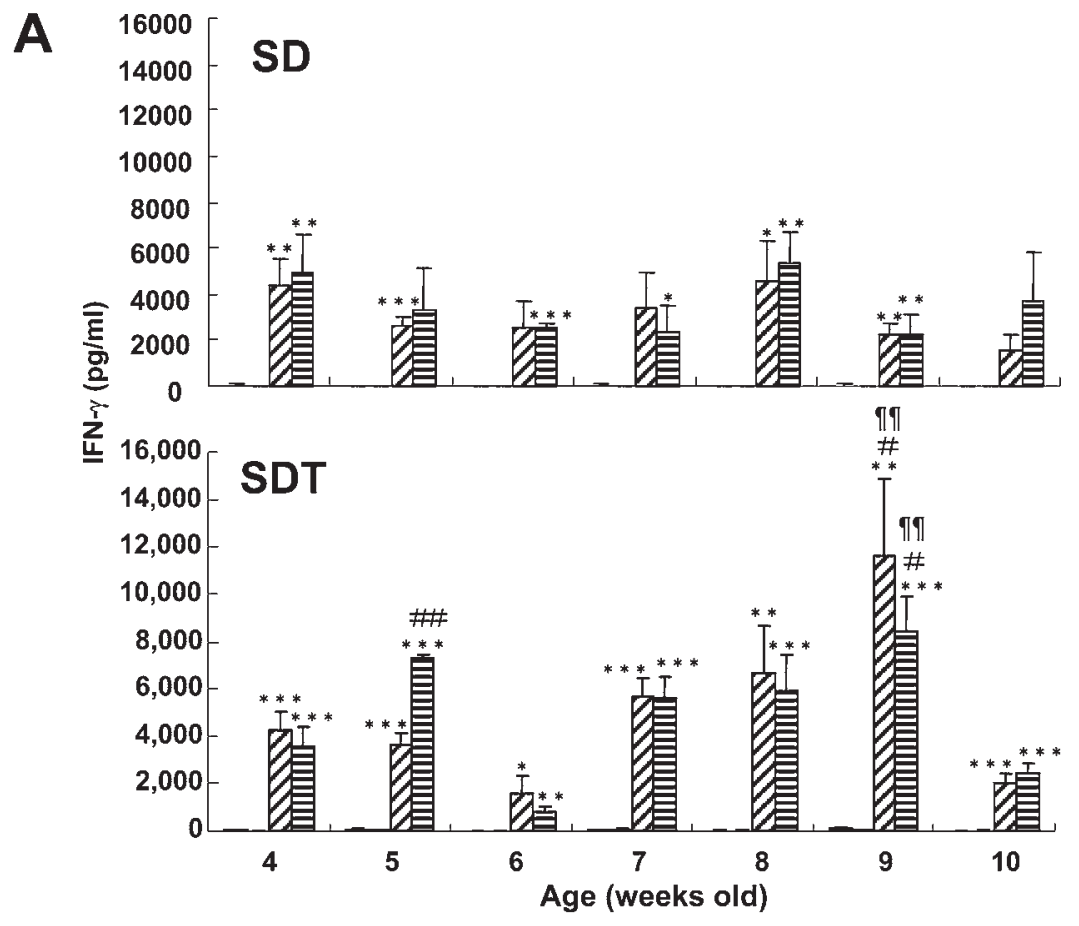

B

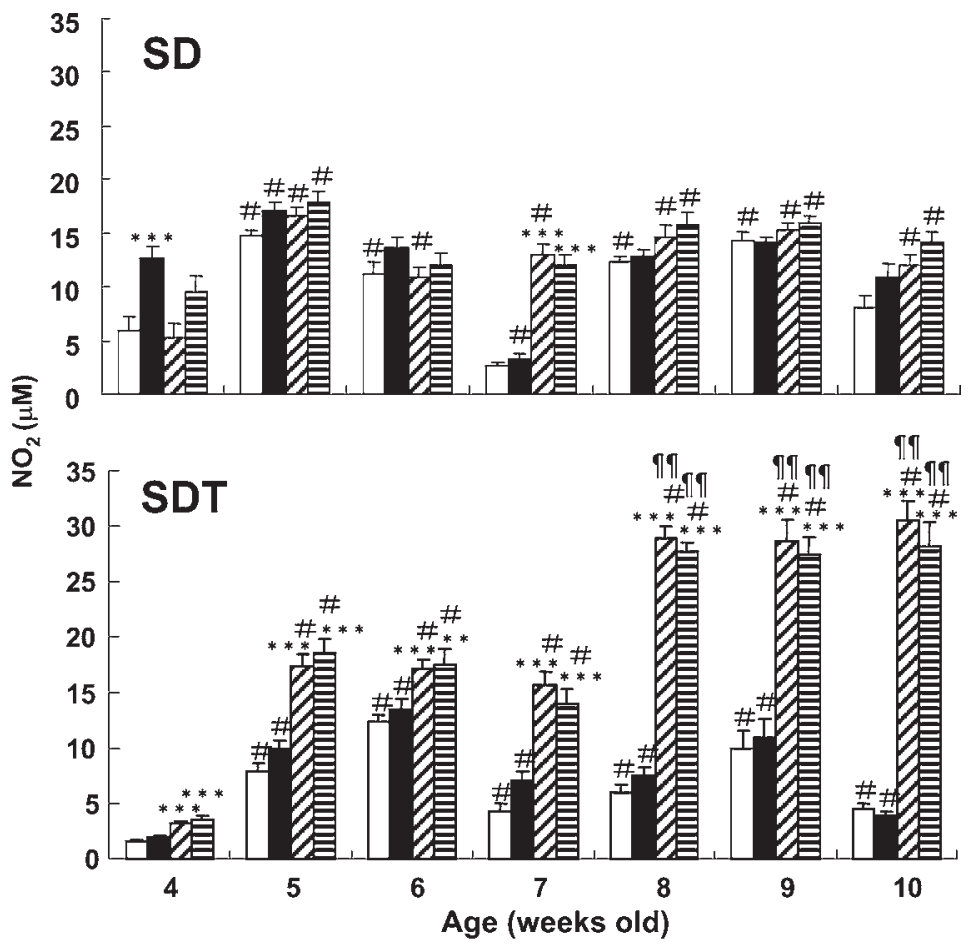

Fig. 4. Cytokine-induced IFN- $\gamma$ production in splenocytes and $\mathrm{NO}_{2}$ production in peripheral leukocytes isolated from SD and SDT rats in vitro. (A) SD and SDT splenocytes from SD and SDT rats of 4 to 10 weeks of age were cultured for $48 \mathrm{~h}$ with none (open columns), IL-12 (closed columns), IL-18 (shaded columns), and IL-12+IL-18 (hatched columns) and assayed for IFN- $\gamma$. Data are expressed as the mean $\pm \mathrm{SE}(\mathrm{n}=8)$. ${ }^{*} P<0.05$, $* * P<0.01$, *** $P<0.001$, comparison with none, and ${ }^{\#} P<0.05$, ${ }^{\# \#} P<0.01$, comparison with 4- week old SD and SDT rats, and "I $P<0.01$, comparison between SD and SDT rats (Student's $t$-test). (B) SD and SDT peripheral leukocytes from SD and SDT rats of 4 to 10 weeks of age were cultured for $48 \mathrm{~h}$ with none (open columns), IL-12 (closed columns), IL-18 (shaded columns), and IL-12+IL-18 (hatched columns) and assayed for $\mathrm{NO}_{2}$. Data are expressed as the mean $\pm \mathrm{SE}(\mathrm{n}=8)$. $* P<0.05$, ** $P<0.01$, *** $P<0.001$, comparison with none, and ${ }^{\#} P<0.05$, comparison with 4-week-old SD and SDT rats, and ${ }^{\text { }} P<0.01$, comparison between SD and SDT rats (Student's $t$-test). 

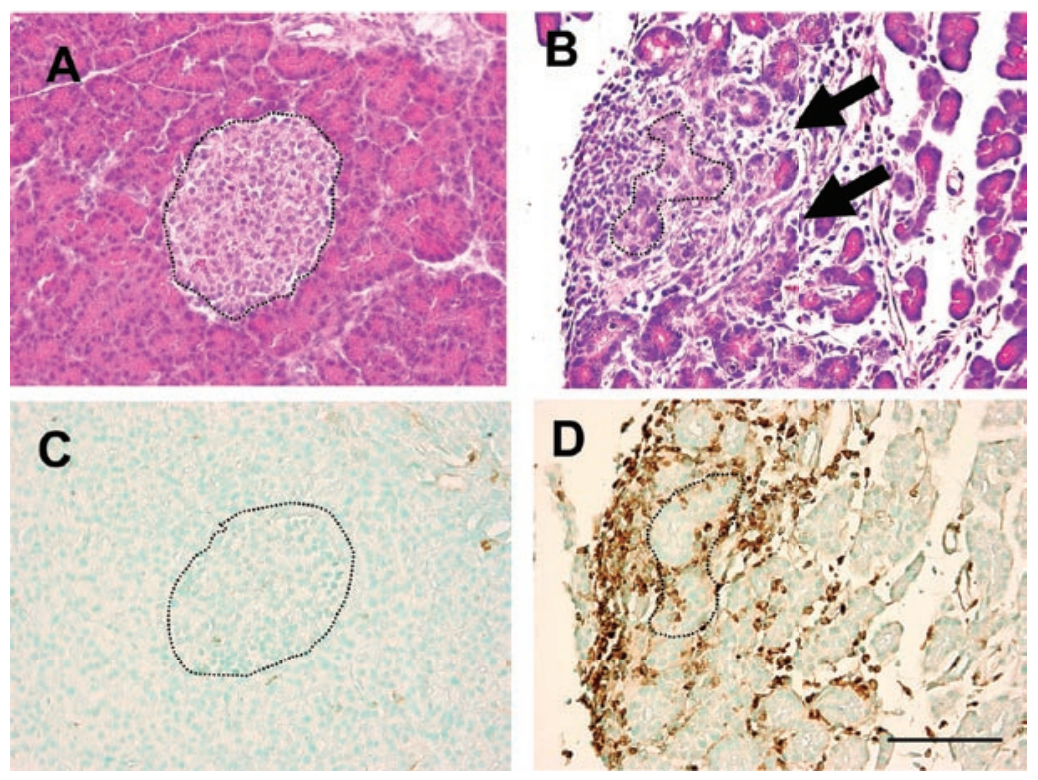

Fig. 5. Histological changes in the pancreatic islets of SDT rats. Paraffin-embedded sections of the pancreas of 4- and 9-week-old SDT rats were stained with HE or anti-CD68 antibody and examined under a microscope. (A) An intact pancreatic islet of a 4-week-old SDT rat (HE), (B) inflammatory cell infiltration (arrows) in the islet of a 9-week-old SDT rat (HE), (C) immunohistochemical staining of macrophages with CD68 (brown) in the islet of a 4-week-old SDT rats, (D) immunohistochemical staining of macrophages with CD68 (brown) in the islet of a 9-week-old SDT rats. (Scale bar $=100 \mu \mathrm{m}$ ).

bination of IL-12 and IL-18 is known to synergistically upregulate IFN- $\gamma$ production in lymphocytes, the combination failed to do so in this study. These results show that the ability to produce IFN- $\gamma$ in response to IL-18 was augmented in the splenocytes of 9-week-old SDT rats.

$\mathrm{NO}_{2}$ production in $\mathrm{SD}$ and $\mathrm{SDT}$ rats peripheral leukocytes induced by $I L-12$ and $I L-18$

In the presence of IL-12, $\mathrm{NO}_{2}$ produced in the culture of leukocytes from SD and SDT rats was less than 17 $\mu \mathrm{M}$, with no significant age-dependent differences (Fig. $4 \mathrm{~B})$. In the presence of IL-18, $\mathrm{NO}_{2}$ production increased with age: $3.1 \pm 0.3,15.0-17.0$, and $30.0 \mu \mathrm{M}$ for $4-, 5$ - to 7-, and 8- to 10-week-old rats, respectively (Fig. 4B). $\mathrm{NO}_{2}$ production was more efficiently induced by IL-18 in the splenocytes from SDT rats at around 9 weeks of age than in the cells from age-matched SD rats (Fig. 4B). A combination of IL-12 and IL-18 did not exhibit a synergistic effect on the production of $\mathrm{NO}_{2}$ (Fig. 4B)
Histological examination of the pancreas of SDT rats

Histological examination of the pancreas showed that the islets of 4-week-old SDT rats were free from infiltration by inflammatory cells (Fig. 5A). However, in the pancreases of 9-week-old SDT rats, inflammatory cells were observed in and around the islets (Fig. 5B). Immunohistochemical analysis using antibody to CD68 (macrophage marker) showed vigorously infiltrating $\mathrm{CD}^{+} 8^{+}$cells in the pancreas of 9-week-old SDT rats, while they were absent in the pancreases of 4-week-old rats (Figs. 5C and 5D).

Treatment with $\mathrm{Cl}_{2} \mathrm{MDP}$-liposomes reduced the number of leukocytes, monocytes, and levels of NO metabolites in the circulation and inhibited macrophage invasion in the islets

We examined the effect of removal of monocytes/ macrophages with $\mathrm{Cl}_{2} \mathrm{MDP}$-liposomes on the number of monocytes in the circulation and on the infiltration of macrophages into the islets of 9-week-old SDT rats (Fig. 6). We found a significant reduction in the number of 

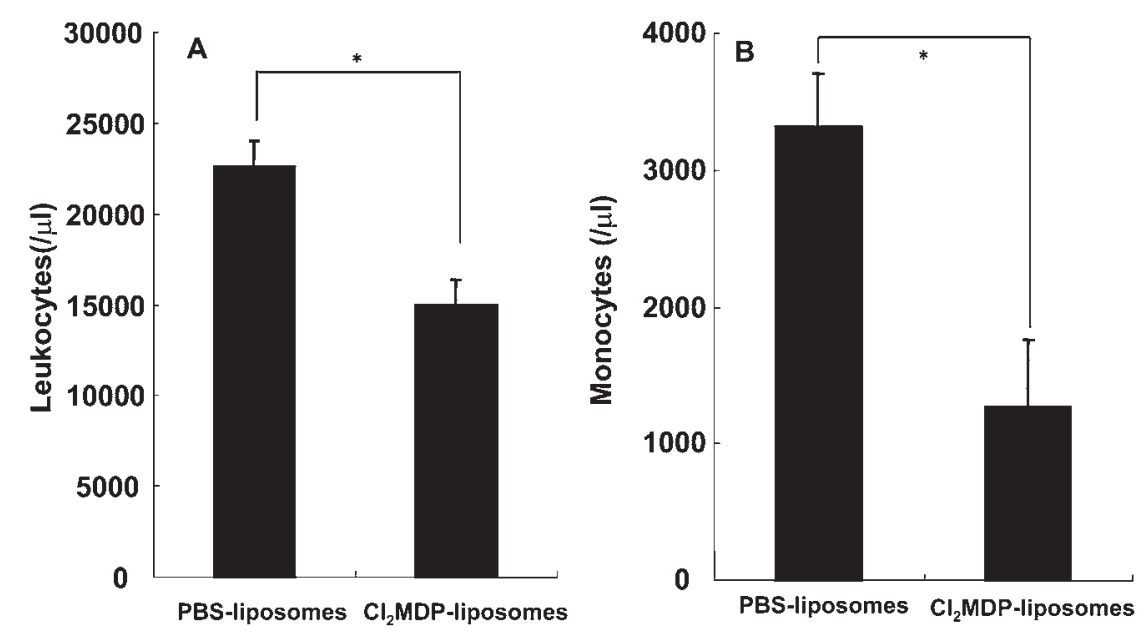

Fig. 6. Reduction of leukocytes and monocytes in SDT rats by treatment with $\mathrm{Cl}_{2} \mathrm{MDP}-1 \mathrm{i}-$ posomes. (A) Leukocytes in SDT rats treated with PBS-liposomes (control) and $\mathrm{Cl}_{2}$ MDP-liposomes. (B) Monocytes in SDT rats treated with PBS-liposomes (control) and $\mathrm{Cl}_{2}$ MDP-liposomes. Data are expressed as the mean $\pm \mathrm{SE}$ of three rats of each group. ${ }^{*} P<0.05$, comparison between PBS-liposomes and $\mathrm{Cl}_{2} \mathrm{MDP}$-liposomes (Student's $t$-test).

circulating leukocytes (Fig. 6A), monocytes in particular (Fig. 6B).

$\mathrm{Cl}_{2} \mathrm{MDP}$-liposome treatment also resulted in a reduction in the number of infiltrating macrophages in the pancreas of SDT rats. Treated rats showed essentially no fibrosis in and around the islets and much fewer infiltrating cells in the islets (Figs. 7B and 7E) as compared to control rats (Fig. 7A). In particular, only a few infiltrating $\mathrm{CD} 8^{+}$cells were observed in the islets of treated rats (Fig. 7D). These results show that treatment of SDT rats with $\mathrm{Cl}_{2}$ MDP-liposomes improved infiltration of macrophages in the pancreas. Treatment of $\mathrm{Cl}_{2} \mathrm{MDP}$ liposomes also inhibited an increase of NO metabolites in serum of SDT rats. As expected from the histological results, $\mathrm{Cl}_{2} \mathrm{MDP}$-liposome treatment suppressed serum $\mathrm{NO}_{2} / \mathrm{NO}_{3}$ levels in 9-week-old SDT rats (Figs. $3 \mathrm{C}$ and $7 \mathrm{~F})$.

\section{Discussion}

It has been reported that higher white blood cell counts may predict the development of impaired fasting glucose or type 2 diabetes in middle-aged Japanese men [21]. For adults in the United States, raised leukocyte counts have been shown to be associated with type 2 diabetes onset [8]. However, the significance of this leukocytosis in relation to diabetes has not been elucidated. SDT rats have been considered to develop type 2 diabetes. In the present study, the roles of inflammatory cells in the destruction of $\beta$-cells in the pancreatic islets were examined. We found that SDT rats exhibited significant leukocytosis at 4 to 10 weeks of age in comparison to SD rats (Fig. 1). Leukocytes that increased in number in SDT rats at 8 to 10 weeks of age included $\mathrm{CD} 3^{+} \mathrm{CD} 4^{+}$ cells (Fig. 2A), $\mathrm{CD}^{+} \mathrm{CD}^{+}$cells (Fig. 2B), $\mathrm{CD} 3^{-} \mathrm{CD} 161 \mathrm{a}^{+}$ NK cells (Fig. 2D), $\mathrm{CD}^{-} \mathrm{Gr}^{-} 1^{+}$neutrophils (Fig. 2E), and most notably $\mathrm{CD}^{-}{ }^{-} \mathrm{CD} 4^{+}$monocytes (Fig. 2C). Concomitantly, serum levels of IL-18 (Fig. 3A) and $\mathrm{NO}_{2} /$ $\mathrm{NO}_{3}$ (Fig. 3C) increased in 9-week-old SDT rats. No such changes were observed in SD rats (Figs. 3A and 3C). However, in the presence of IL-18, splenocytes from SDT rats, particularly those at 9 weeks of age produced high levels of IFN- $\gamma$ (Fig. 4A). Levels of $\mathrm{NO}_{2}$ in leukocytes from SDT rats were also elevated in the presence of IL-18 (Fig. 4B). Serum $\mathrm{NO}_{2} / \mathrm{NO}_{3}$ levels were lower in 10-week-old SDT rats than those in 9-week-old SDT rats (Figs. 3A and 3C), which may reflect a rapid decrease in circulating IL-18 levels after 9 weeks of age. It has been demonstrated that excess NO production plays a crucial role in islet injury in NOD mice [6]. In 

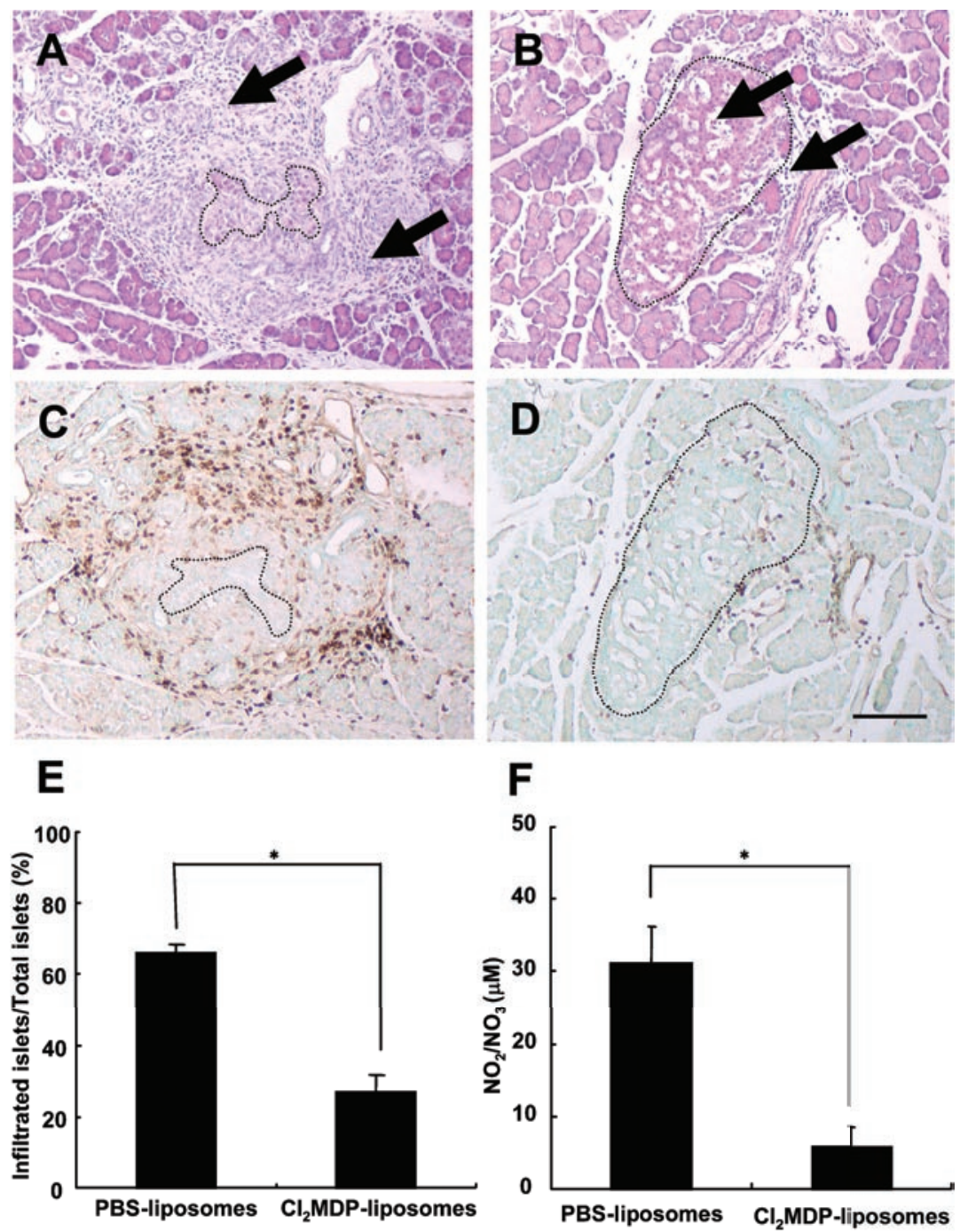

Fig. 7. Effect of $\mathrm{Cl}_{2} \mathrm{MDP}$-liposomes treatment on histological changes of the pancreatic islets of 9-week-old SDT rats and serum $\mathrm{NO}_{2} / \mathrm{NO}_{3}$ concentration. (A) An islet of a 9-week-old SDT rat treated with PBS-liposomes (HE), (B) An islet of a 9-week-old SDT rats treated with $\mathrm{Cl}_{2} \mathrm{MDP}$-liposomes (HE). Arrows show inflammatory cells. (C) Macrophages stained with CD68 (brown) in an islet of a 9-week-old SDT rat treated with PBS-liposomes (control). (D) Macrophages stained with CD68 (brown) in an islet of a 9-week-old SDT rat treated with $\mathrm{Cl}_{2}$ MDP-liposomes. (Scale bar $=100 \mu \mathrm{m}$ ). (E) Comparison of inflammatory cell infiltration of pancreatic islets of 9-week-old SDT rats treated with PBS-liposomes (control) and $\mathrm{Cl}_{2} \mathrm{MDP}$-liposomes. Islets infiltrated with inflammatory cells were counted and expressed as a proportion of the total islets of the same pancreas. More than 50 pancreatic islets were analyzed per rat. (F) Concentration of serum $\mathrm{NO}_{2} / \mathrm{NO}_{3}$ in 9-week-old SDT rats treated with PBS-liposomes (control) and $\mathrm{Cl}_{2}$ MDP-liposomes. Data are expressed as the mean $\pm \mathrm{SE}$ of three rats of each group. Data are expressed as the mean $\pm \mathrm{SE}$ of 3 rats of each group. $* P<0.05$, comparison between PBS-liposomes and $\mathrm{Cl}_{2} \mathrm{MDP}$-liposomes (Student's $t$-test).

SDT rats, high levels of production of $\mathrm{NO}$ as well as those of IL-18 were transient and in parallel (Figs. 3A and $3 \mathrm{C}$ ). The reason for this finding was not clear. How- ever, it has been reported that IL-18, when administered to mice, causes production of a large amount of $\mathrm{NO}$ in an IFN- $\gamma$-dependent manner [4]. Since IL-18 stimulates 
IFN- $\gamma$ production, it is probable that IL- 18 activates IRF1 that is known to be activated via IFN- $\gamma$. In addition, IL-18 has been shown to activate NF- $\kappa \mathrm{B}$ and NF-AT, which are essential for IFN- $\gamma$ production [35]. Thus, IL-18 is likely to be involved in iNOS induction.

IL-12 is a proinflammatory cytokine. The biologically active IL-12 is a 70-kDa heterodimer (IL-12p70), with 40-kDa (p40) and 35-kDa (p35) subunits [10]. IL$12 \mathrm{p} 40$ is expressed and secreted in large excess over IL-12p70 [11, 24]. It has been demonstrated that IL$12 p 40$ blocks the activities of IL-12p70, leading to the suggestion that IL-12p40 serves as a natural antagonist of IL-12p70 [9]. In this study, serum levels of IL-12p40 ranged from 800 to $1,300 \mathrm{pg} / \mathrm{ml}$ throughout the experimental period in SDT rats (Fig. 3B), and serum levels of IL-12p70 were not detected throughout the experimental period (data not shown), suggesting that the SDT rats were in an immune-suppressive condition.

It has been suggested that elevated levels of IL-18 predict the development of type 2 diabetes [34]. However, in young NOD mice developing type 1 diabetes, systemic administration of IL-18 promotes the development of diabetes [23] and IL-18 blockade with IL-18binding protein (BP) delays its onset [39]. IL-18 also contributes to the injury of islets in diabetic mice induced by multiple low doses of streptozotocin (STZ) [22]. These results suggest that IL-18 is profoundly involved in the pathogenesis of type 1 diabetes through upregulation of IFN- $\gamma$ and NO synthesis. The present study using SDT rats suggests that IL-18 is involved in the development of type 2 diabetes in a way similar to that of type 1 diabetes.

Masuyama et al. have reported the presence of inflammatory cells in and around the islets of 10-week-old SDT rats, suggesting that inflammatory cell infiltration is an important factor in islet destruction [20].

It has been shown that a large number of macrophages are present in the pancreas of neonatal NOD mice [36]. Macrophages are among the first cells to infiltrate the islets, and when fully activated can exert cytotoxicity against $\beta$-cells via excess production of TNF- $\alpha$ and reactive oxygen intermediates such as $\mathrm{NO}[18,32,33]$. In this study, we found infiltration of macrophages in and around the islet of 9-week-old SDT rats (Fig. 5D). This occurred in parallel with raised serum levels of
IL-18 and $\mathrm{NO}_{2} / \mathrm{NO}_{3}$, forming a prominent peak at around 9 weeks of age. These results suggest that infiltrating macrophages produce a large amount of NO by the induction of IL-18 and IFN- $\gamma$, resulting in damage to the islets. The mechanism of the progressive injury of the islets after 9 weeks of age was not explored in this study. Shinohara et al. have reported that infiltrating cells in and around the islets include lymphocytes and macrophages [30]. We speculate that the pancreatic islets of SDT rats may be injured by excess NO produced by macrophages at 9 weeks of age, and subsequently by infiltrating lymphocytes.

$\mathrm{Cl}_{2} \mathrm{MDP}$-liposomes are known as a potent anti-macrophage agent [38] which is useful for the treatment of various diseases in animal models [1,13]. In this study, we found that treatment of 6-week-old SDT rats with $\mathrm{Cl}_{2}$ MDP-liposomes prevented infiltration of macrophages into the pancreas (Figs. 7D and 7E). At the same time, serum NO levels were low in the treated SDT rats as compared to control rats (Fig. 7F).

In summary, treatment with $\mathrm{Cl}_{2} \mathrm{MDP}$-liposomes decreased serum levels of $\mathrm{NO}_{2} / \mathrm{NO}_{3}$ and reduced invasion of macrophages in the pancreatic islets of SDT rats. This suggests that macrophages play an important role in pancreatic islet injury in SDT rats.

\section{Acknowledgment(s)}

We thank the Association for the Spontaneously Diabetic Torii Rat for providing the SDT rats and Naomi Gamachi and Fumie Katsube for excellent technical assistance.

\section{References}

1. Alves-Rosa, F., Stanganelli, C., Cabrera, J., van Rooijen, N., Palermo, M.S., and Isturiz, M.A. 2000. Treatment with liposome-encapsulated clodronate as a new strategic approach in the management of immune thrombocytopenic purpura in a mouse model. Blood 96: 2834-2840.

2. Arnush, M., Heitmeier, M.R., Scarim, A.L., Marino, M.H., Manning, P.T., and Corbett, J.A. 1998. IL-1 produced and released endogenously within human islets inhibits beta cell function. J. Clin. Invest. 102: 516-526.

3. Arnush, M., Scarim, A.L., Heitmeier, M.R., Kelly, C.B., and Corbett, J.A. 1998. Potential role of resident islet macrophage activation in the initiation of autoimmune diabetes. $J$. Immunol. 160: 2684-2691. 
4. Chikano, S., Sawada, K., Shimoyama, T., Kashiwamura, S.I., Sugihara, A., Sekikawa, K., Terada, N., Nakanishi, K., and Okamura, H. 2000. IL-18 and IL-12 induce intestinal inflammation and fatty liver in mice in an IFN-gamma dependent manner. Gut 47: 779-786.

5. Corbett, J.A. and McDaniel, M.L. 1995. Intraislet release of interleukin 1 inhibits $\beta$ cell function by inducing $\beta$ cell expression of inducible nitoric oxide synthase. J. Exp.Med. 181: 559-568.

6. Corbett, J.A., Mikhael, A., Shimizu, J., Frederick, K., Misko, T.P., McDaniel, M.L., Kanagawa, O., and Unanue, E.R. 1993. Nitric oxide production in islets from nonobese diabetic mice: aminoguanidine-sensitive and -resistant stage in the immunological diabetic process. Proc. Natl. Acad. Sci. U.S.A. 90: 8992-8995.

7. Danenberg, H.D., Fishbein, I., Gao, J., Monkkonen, J., Reich, R., Gati, I., Moerman, E., and Golomb, G. 2002. Macrophage depletion by clodronate-containing liposomes reduces neointimal after balloon injury in rats and rabbits. Circulation 106: 599-605.

8. Ford, E.S. 2002. Leukocyte count, erythrocyte sedimentation rate, and diabetes incidence in a national sample of US adults. Am. J. Epidemiol. 155: 57-64.

9. Gillessen, S., Carvajal, D., Ling, P., Podlaski, F.J., Stremlo, D.L., Familletti, P.C., Gubler, U., Presky, D.H., Stern, A.S., and Gately, M.K. 1995. Mouse interleukin-12 (IL-12) p40 homodimer: a potent IL-12 antagonist. Eur. J. Immunol. 25: 200-206.

10. Gubler, U., Chua, A.O., Schoenhant, D.S., Dwyer, C.M., McComas, W., Motyka, R., Nabavi, N., Wolitzky, A.G., Quinn, P.M., Familletti, P.C., and Gately, M.K. 1991. Coexpression of two distinct genes is required to generate secreted bioactive cytotoxic lymphocyte maturation factor. Proc. Natl. Acad. Sci. U.S.A. 88: 4143-4147.

11. Heinzel, F.P., Rerko, R.M., Ling, P., Hakimi, J., and Schoenhaut, D.S. 1994. Interleukin 12 is produced in vivo during endotoxemia and stimulates synthesis of gamma interferon. Infect. Immun. 62: 4244-4249.

12. Hong, T.P., Andersen, N.A., Nielsen, K., Karlsen, A.E., Fantuzzi, G., Eizirik, D.L., Dinarello, C.A., and MandrupPoulsen, T. 2000. Interleukin-18 mRNA, but not interleukin-18 receptor mRNA, is constitutuvely expressed in islet bete-cells and up-regulated by interferon-gamma. Eur. Cytokine Netw. 11: 193-205.

13. Huitinga, I., van Rooijen, N., de Groot, C.J., Uitdehaag, B.M., and Dijkstra, C.D. 1990. Suppression of experimental allergic encephalomyelitis in Lewis rats after elimination of macrophages. J. Exp. Med. 172: 1025-1033.

14. Jansen, A., Homo-Delarche, F., Hooikaas, H., Leenen, P.J., Derdenne,M., and Drexhage,H.A.1994.Immunohistochemical characterization of monocytes-macrophages and dendritc cells involved in the initiation of the insulitis and beta-cell destruction in NOD mice. Diabetes 43: 667-675.

15. Jordan, M.B., van Rooijen, N., Izui, S., Kappler, J., and Marrack, P. 2003. Liposomal clodronate as a novel agent for treating autoimmune hemolytic anemia in a mouse model. Blood 101: 594-601.

16. Kroncke, K.D., Rodriguez, M.L., Kolb, H., and Kolb-
Bachofen, V. 1993. Cytotoxicity of activated rat macrophages against sygeneic islet cells is arginine-dependent, correlates with citrulline and nitrite concentrations and is identical to lysis by the nitric oxide donor nitroprusside. Diabetologia 36: 17-24.

17. Lasbury, M.E., Durant, P.J., Ray, C.A., Tschang, D., Schwendener, R., and Lee, C.H. 2006. Suppression of alveolar macrophages apoptosis prolongs survival of rats and mice with pneumocystis pneumonia. J. Immunol. 176: 6443-6453.

18. Laychock, S.G., Sessanna, S.M., Lin, M.H., and Mastrandrea, L.D. 2006. Sphingosine 1-phosphate affects cytokineinduced apoptpsis in rat pancreatic islet beta-cells. Endocrinology 147: 4705-4712.

19. Mandrup-poulsen, T., Helqvist, S., Wogensen, L.D., Molvig, J., Pociot, F., Johannesen, J., and Nerup, J. 1990. Cytokine and free radicals as effector molecules in the destruction of pancreatic beta cells. Curr. Top Microbiol. Immunol. 164: 169-193.

20. Masuyama, T., Komeda, K., Hara, A., Noda, M., Shinohara, M., Oikawa, T., Kanazawa, Y., and Taniguchi, K. 2004. Choronological characterization of diabetes development in male Spontaneously Diabetic Torii rats. Biochem. Biophys. Res. Commun. 314: 870-877.

21. Nakanishi, N., Yoshida, H., Matsuo, Y., Suzuki, K., and Tatara, K. 2002. White blood-cell count and the risk of impaired fasting glucose or Type II diabetes in middle-aged Japanese men. Diabetologia 45: 42-48.

22. Nicoletti, F., Di Marco, R., Papaccio, G., Conget, I., Gomis, R., Bernardini, R., Sims, J.E., Shoenfeld, Y., and Bendtzen, K. 2003. Essential pathogenic role of endogenous IL-18 in murine diabetes induced by multiple low doses of streptozotocin. Prevention of hyperglycemia and insulitis by a recombinant IL-18-binding protein: Fc construct. Eur. J. Immunol. 33: 2278-2286.

23. Oikawa, Y., Shimada, A., Kasuga, A., Morimoto, J., Osaki, T., Tatara, H., Miyazaki, T., Tashiro, F., Yamato, E., Miyazaki, J., and Saruta, T. 2003. Systemic administration of IL-18 promotes diabetes development in young nonobese diabetic mice. J. Immunol. 171: 5865-5875.

24. Podlaski, F.J., Nanduri, V.B., Hulmes, J.D., Pan, Y.C., Levin, W., Danho, W., Chizzonite, R., Gately, M.K., and Stern, A.S. 1992. Molecular characterization of interleukin 12. Arch. Biochem. Biophys. 294: 230-237.

25. Rabinovitch, A., Suarez-Pinzon, W.L., Sorensen, O., and Bleackley, R.C. 1996. Inducible nitric oxide synthase (iNOS) in pancreatic islets of nonobese diabetic mice: identification of iNOS-expressing cells and relationships to cytokines expressed in the islets. Endocrinology 137: 2093-2099.

26. Rabinovitch, A., Suarez-Pinzon, W.L., Sorensen, O., Bleackley, R.C., and Power, R.F. 1995. IFN-gamma gene expression in pancreatic islet-infiltrating mononuclear cells correlates with autoimmune diabetes in nonobese diabetic mice. J. Immunol. 154: 4874-4882.

27. Rodan, G.A. 1998. Mechanisms of action of bisphosphonates. Annu. Rev. Pharmacol. Toxicol. 38: 375-388.

28. Rosmalen, J.G., Matrin, T., Dobbs, C., Voerman, J.S., Drexhage, H.A., Haskina, K., and Leenen, P.J. 2000. Subsets 
of macrophages and dendritic cells in nonobese diabetic mouse pancreatic inflammatory infiltrates: correlation with the development of diabetes. Lab. Invest 80: 23-30.

29. Selander, K.S., Monkkonen, J., Karhukorpi, E.K., Harkonen, P., Hannuniemi, R., and Vaananen, H.K. 1996. Characteristics of clodronate-induced apoptosis in osteoclasts and macrophage. Mol. Pharmacol. 50: 1127-1138.

30. Shinohara, M., Masuyama, T., Shoda, T., Takahashi, T., Katsuda, Y., Komeda, K., Kuroki, M., Kakehashi, A., and Kanazawa, Y. 2000. A new spontaneously diabetic non-obese Torii rats strain with severe ocular complications. Int. J. Exp. diabetes Res. 1: 89-100.

31. Simpson, P.B., Mistry, M.S., Maki, R.A., Yang, W., Schwarz, D.A., Johnson, E.B., Lio, F.M., and Alleva, D.G. 2003. Cutting edge: diabetes-associated quantitative trait locus, Idd4, is responsible for the IL-12p40 overexpression defect in nonobese diabetic (NOD) mice. J. Immunol. 171: 3333-3337.

32. Steer, S.A., Maran, J.M., Christmann, B.S., Maggi, L.B. Jr., and Corbett, J.A. 2006. Role of MAPK in the regulation of double-stranded RNA-and encephalomyocarditis virusinduced cyclooxygenase- 2 expression by macrophages. $J$. Immunol. 177: 3413-3420.

33. Steer, S.A., Scarim, A.L., Chamber, K.T., and Corbett, J.A. 2006. Interleukin-1 stimulates beta-cell necrosis and release of the immunoligocal adjuvant HMGB1. PLoS Med. 3: e17.

34. Thorand, B., Kolb, H., Baumert, J., Koenig, W., Chambless,
L., Meisinger, C., Illig, T., Martin, S., and Herder, C. 2005. Elevated levels of interleukin-18 predict the development of type 2 diabetes: results from the MONICA/KORA Augsburg Study, 1984-2002. Diabetes 54: 2932-2938.

35. Tsuji-Takayama, K., Aizawa, Y., Okamoto, I., Kojima, H., Koide, K., Takeuchi, M., Ikegami, H., Ohta, T., and Kurimoto, M. 1999. Interleukin-18 induced interferongamma production through NF-kappaB and NFAT activation in murine T helper type 1 cells. Cell Immunol. 196: 4150.

36. Unanue, E., Byersdorfer, C., Carrero, J., Levisetti, M., Lovitch, S., Pu, Z., and Suri, A. 2005. Antigen presentation: lysolyme, autoimmune diabetes, and Listeria-what do they have in common? Immunol. Res. 32: 267-292.

37. van Rooijen, N. and Sanders, A. 1994. Liposomes mediated depletion of macrophages: mechanism of action, preparation of liposomes and applications. J. Immunol. Methods 174: 83-93.

38. van Rooijen, N. and van Nieuwmegen, R. 1984. Elimination of phagocytic cells in the spleen after intravenous injection of liposome-encapsuletes dichloromethylene diphosphonate. An enzyme-histochemical study. Cell Tissue Res. 238: 355-358.

39. Zaccone, P., Phillips, J., Conget, I., Cooke, A., and Nicoletti, F. 2005. IL-18 binding protein fusion construnt delay the development of diabetes in adoptive transfer and cyclophosphamide-induced diabetes in NOD mouse. Clin. Immunol. 115: 74-79. 